\title{
Circuit
}

Musiques contemporaines

\section{Three Violin Concertos}

\section{Andréa Tyniec}

Volume 28, numéro 2, 2018

URI : https://id.erudit.org/iderudit/1051300ar

DOI : https://doi.org/10.7202/1051300ar

Aller au sommaire du numéro

\section{Éditeur(s)}

Circuit, musiques contemporaines

\section{ISSN}

1183-1693 (imprimé)

1488-9692 (numérique)

Découvrir la revue

\section{Citer ce document}

Tyniec, A. (2018). Three Violin Concertos. Circuit, 28(2), 112-113.

https://doi.org/10.7202/1051300ar

Ce document est protégé par la loi sur le droit d'auteur. L'utilisation des services d'Érudit (y compris la reproduction) est assujettie à sa politique d'utilisation que vous pouvez consulter en ligne.

https://apropos.erudit.org/fr/usagers/politique-dutilisation/
Cet article est diffusé et préservé par Érudit.

Érudit est un consortium interuniversitaire sans but lucratif composé de l’Université de Montréal, l'Université Laval et l'Université du Québec à Montréal. Il a pour mission la promotion et la valorisation de la recherche. https://www.erudit.org/fr/ 


\section{Three Violin Concertos}

Andréa Tyniec

My relationship with Véronique Lacroix and the ECM+ spans almost 20 years. I was a goth-clad teenager when I first met her and signed up (or was recruited) for the ECM relève, the contemporary music class at the Montreal Conservatory. Since then, I've premiered three violin concertos in collaboration with ECM+, two of which have been recorded for ATMA. Looking back, I see how we've witnessed and supported each other's artistic growth and how our joint performances have shaped the arc of our collaborative relationship.

First of all, the ECM+ and Véronique's presence at school had a huge impact on me artistically. I realized, after graduating and studying abroad, that the kind of training we received at the Conservatory through her program at that time was unique and world-class. Even though I loved contemporary music as a child and growing up, it wasn't until I became her student that I was given the opportunity, the time and the right environment to discover the world of collaboration between composers and instrumentalists. The collaborative process was introduced to me as this vibrant and chaotic path towards mutual understanding, with a strong emphasis on communication, rigorous preparation and a willingness to try to execute new and impossible things. The premieres of new works were satisfying moments of materializing every note and every idea that had been animatedly debated, axed, rewritten, altered and refined during rehearsals, through laughter and tension. It was in those moments of collaborative efforts that I felt, perhaps for the first time, that someone had lifted the line that divided school and real life, and simply allowed me to call what I was doing, making music.

It was in preparation towards premiering André Ristic's violin concerto Projet d'Opéra that I experienced working with ECM+ for the first time in 2003. Since then, I've come to realize that both the core members of the ensemble and those who have come and gone, all shared an adventurous spirit and an open mind, and have shown time and time again their ability to meet difficulties with creative solutions and often much humour to lighten the challenge. I admire and applaud the courage and curiosity with which they approach every new musical language, and how much self-reliance they are equipped with to champion every piece. They've taught me a lot. Like all the best teams, they have the humility and wisdom to set aside what gets in the way of the work, the vision and the performance, and they continue to inspire me, individually and collectively. With each project, ECM+ became an extension to my musical family, especially after travelling with them for the Generationzo14 Tour to perform Alec Hall's violin concerto Object Permanence, and other stunning works by Marie-Pierre Brasset, Evelyn Ramon, and Anthony Tan. And I have much fondness for both Natalie Watanabe and Maude Gareau, for their support in everything that makes great performances possible, more specifically for their attention to detail and to people.

I don't want to imagine what my life would be like if I hadn't met Véronique. When she saw me as a teenager for the first time, she probably saw right through 
my youthful invincibility. But she didn't laugh. Instead, she gave me opportunities to challenge myself. I admire her energy, and the consistency with which she has led her team, nurtured composers, created program after program, and developed a vibrant community around contemporary music. It is a testament to her excellence and strength to have done this consistently for decades.

Early on in my studies, Véronique introduced me to Ana Sokolović, whom I instantly looked up to. As the years went by, I went on to perform many of her violin pieces and I saw our relationship transform into friendship. The idea of a violin concerto had been raised many times, until it finally found a home at the IScm World New Music Days 2017. Leading up to writing Evta, I remember Ana taking notes on some of my most pressing existential concerns during our meetings and, eventually, including them into the structure of the piece. Stepping into the studio on the first day of rehearsal with the $\mathrm{ECM}+$, Véronique and Ana and performing the concerts and recording were amongst the most fulfilling artistic experiences I've had the honour to be part of. I cherish the experience of working in an atmosphere of loyalty, bound by a common understanding that music and life are one and the same, and I'm eager to see where else that can take us in the future.

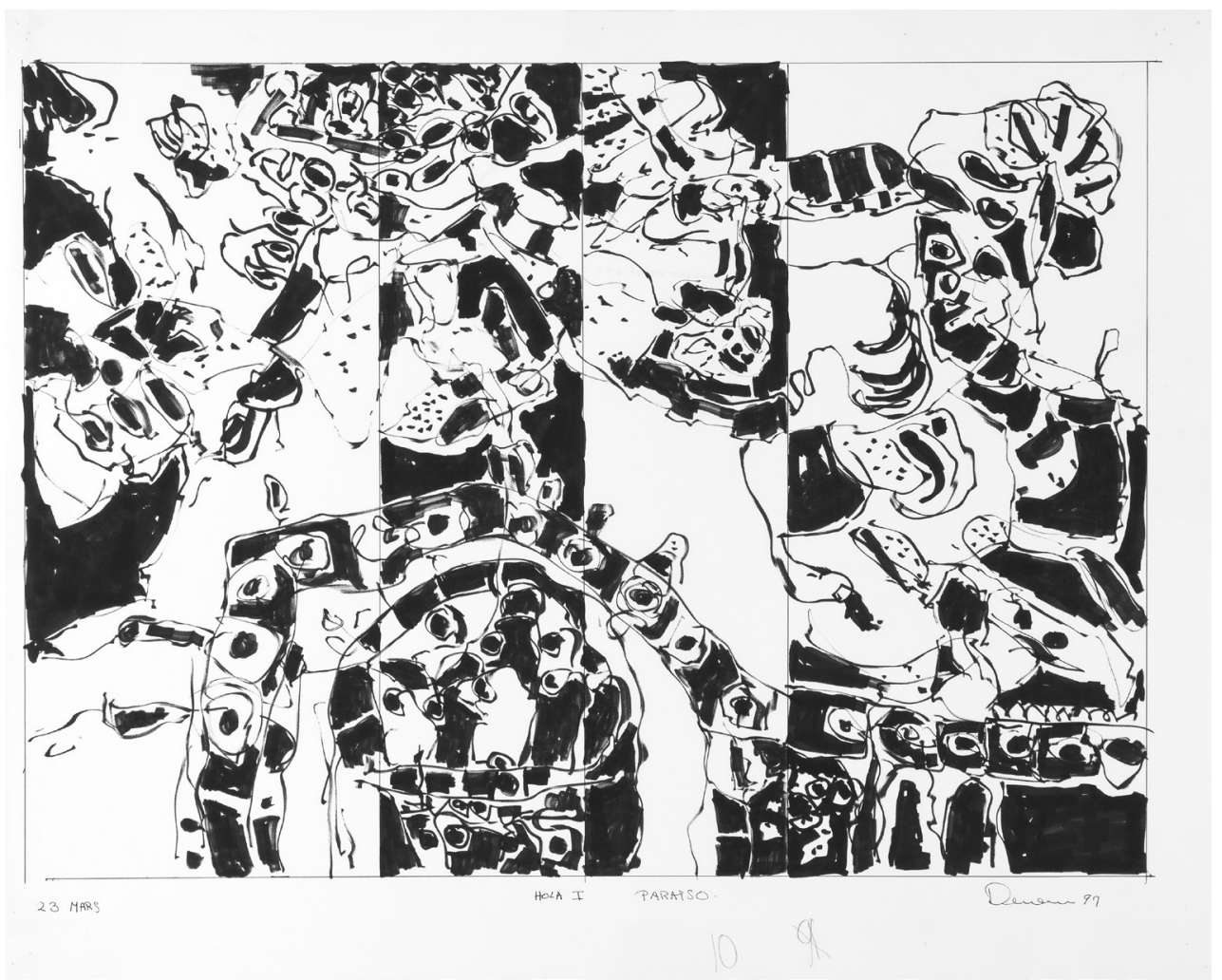

René Derouin, "Hola I", esquisse pour Paraíso. La dualité du baroque, 1997. Dessin à l'encre, $48 \times 60 \mathrm{~cm}$. Musée de la civilisation, don de Michel Lorrain, 2012-441. (C) René Derouin/Sodrac (2018). 